\title{
HUBUNGAN POLA MENYIKAT GIGI DENGAN KARIES GIGI
}

\author{
Ristya Widi Endah Yani \\ Bagian Ilmu Kesehatan Gigi Masyarakat dan Pencegahan, Fakultas Kedokteran Gigi, Universitas Jember
}

Ristya Widi Endah Yani. Hubungan pola menyikat gigi dengan karies gigi. Indonesian Journal of Dentistry 2005; 12 (1): 15-18.

\begin{abstract}
A cross-sectional investigation aimed to establish the relation between the pattern of tooth brushing and dental caries for a non-random (accidental) sample of 140 people, more than 12 years old, in Puger Kulon village. The used instruments and materials were explorer, mouth mirror, deppen glass, neir beken, 70\% alcohol and a questionnaire sheet. The resulting data were analyzed by chi-square test $(\alpha=0.05)$. The results show a significant association of the pattern of tooth brushing with caries, so that an applied pattern of tooth brushing significantly decreased dental caries. Conversely, absent tooth brushing was significantly associated with higher incidence of caries.
\end{abstract}

Keyword : Pattern of tooth brush, caries.

\section{Pendahuluan}

Penyakit karies gigi dapat dialami oleh setiap orang dan dapat timbul pada satu sisi serta dapat meluas ke bagian yang lebih dalam dari gigi. ${ }^{1}$ Plak merupakan penyebab awal terjadinya karies gigi. Oleh karena itu tidak dapat disangkal bahwa setelah makan sedapat mungkin kita harus meniadakan plak.. ${ }^{2} \quad$ Salah satu upaya pencegahan yang dianjurkan atau biasa dilakukan oleh masyarakat adalah tindakan menggosok gigi setiap hari. Untuk memperoleh hasil yang optimal dapat diperoleh dari prosedur menggosok gigi adalah dengan memperhatikan faktor-faktor yang mempengaruhinya yakni tehnik menggosok, waktu, alat yang digunakan, lamanya menggosok dan frekuensi menggosok. Hal tersebut merupakan faktor yang dapat menentukan hasil akhir prosedur menggosok gigi. ${ }^{3}$

Boediharjo (1989) ${ }^{4}$ menyatakan bahwa yang terpenting sebagai upaya menjaga kebersihan mulut adalah faktor kesadaran dan perilaku pemeliharaan higiene mulut masing-masing. ${ }^{4} \mathrm{Hal}$ ini begitu penting karena kegiatannya dilakukan di rumah tanpa ada pengawasan dari siapapun. Sepenuhnya tergantung dari pengetahuan, pemahaman, kesadaran serta kemauan dari fihak individu untuk menjaga kesehatan mulutnya. Pemeliharaan kesehatan mulut tersebut sangat erat kaitannya dengan kontrol plak atau penghilangan plak secara teratur. Untuk tujuan tersebut cara yang paling mudah dan umum dilakukan adalah dengan cara menyikat gigi secara teratur dan benar karena hal tersebut merupakan usaha yang dapat dilakukan secara pribadi. 
Indeks karies adalah angka yang menunjukkan jumlah gigi dengan karies pada seseorang atau sekelompok orang. ${ }^{5}$ Indeks ini diusulkan pertama kali oleh Klein dan digunakan oleh WHO sejak tahun 1977, kemudian WHO juga menentukan kriteria DMF-T dan def-T rata-rata tentang tinggi rendahnya untuk suatu daerah/negara kriteria tersebut sebagai berikut :

\section{Tabel 1. Nilai def-T/DMF-T dan kriteria yang} digunakan.

\begin{tabular}{cc}
\hline Nilai def-T/DMF-T & Kriteria \\
\hline $0,0-1,1$ & Sangat rendah \\
$1,2-2,6$ & Rendah \\
$2.7-4.4$ & Sedang \\
$4,5-6.6$ & Tinggi \\
$>6,6$ & Sangat tinggi \\
\hline
\end{tabular}

\footnotetext{
Keterangan :

$\mathrm{D}=$ Decay : gigi karies yang masih dapat ditumpat

$\mathrm{M}=$ Missing : gigi yang hilang disebabkan karena karies/ indikasi cabut

$F=$ Filled : gigi yang sudah ditumpat dan masih baik.

$\mathrm{d}=$ decay : gigi sulung karies yang masih dapat ditambal

$\mathrm{c}=$ exfoliasi : gigi sulung yang telah/ harus dicabut karena karies

$\mathrm{f}=$ filling : gigi sulung yang telah ditambal

$\uparrow=$ tooth : gigi
}

Berdasarkan hal tersebut maka timbul permasalahan apakah ada hubungan antara pola menyikat gıgi dengan karies gigi. Tujuan penelitian ini adalah untuk mengetahui hubungan antara pola menyikat gigi dengan karies gigi penduduk desa Puger Kulon.

\section{Bahan dan Cara Kerja}

Populasi penelitian adalah penduduk desa Puger Kulon usia 12 tahun ke atas sebesar 5978 jiwa. 'Besar sampel dihitung dengan rumus :

$d=Z \times \sqrt{\frac{p \times q}{n}} \times \sqrt{\frac{N-n}{N-1}}$

Keterangan :

d : penyimpangan terhadap populasi atau derajat kemaknaan yang diinginkan, biasanya 0,05 atau 0,001

$Z$ : standar deviasi normal, biasanya ditentukan pada 1,95 atau 2,0 yang sesuai dengan derajat kemaknaan $95 \%$ $\mathrm{p}$ : proporsi untuk sifat tertentu yang diperkirakan terjadi pada populasi. Apabila tidak diketahui proporsi atau sifat tertentu tersebut maka $\mathrm{p}=0,05$

\section{$\mathrm{q}: 1,0-\mathrm{p}$}

$\mathrm{N}$ : besarnya populasi

$\mathrm{N}$ : besarnya sampel (Notoatmodjo, 1993).

Hasil penghitungan menunjukkan 71 sampel. Untuk memperbesar nilai kemaknaan jumlah sampel menjadi 140. Teknik pengambilan sampel dengan non random sampling (accidental), dengan kriteria sampel yaitu bersedia menjadi sampel, berada di tempat pada saat penelitian, laki-laki atau perempuan berusia 12 tahun ke atas, masih mempunyai gigi (tidak edentulous). Alat dan bahan penelitian yaitu sonde, kaca mulut, deppen glass, neir bekken, kuesioner, alkohol 70\%. Data diperoleh dengan menghitung DMF-T masingmasing individu dan kuisioner, kemudian ditabulasikan dalam bentuk tabel dan dianalisis dengan uji chi-square dengan $\alpha=0,05$

\section{Hasil}

Dari hasil pengumpulan data yang diperoleh melalui pengisian kuisioner dengan metode wawancara langsung dan pemeriksaan gigi untuk melihat DMF-T tiap sampel penelitian dengan jumlah sampel 140 orang, dibuat Tabel 2 distribusi karies, jumlah dan prosentasenya tercantum pada Tabel 2.

Dari Tabel 2 terlihat bahwa kriteria DMF-T sangat rendah tidak ada, dan kriteria DMF-T rendah berjumlah 13 orang $(9,28 \%)$. Kriteria DMF-T sedang berjumlah 82 orang $(58,57 \%)$. Kriteria DMF-T tinggi berjumlah 40 orang $(28,57 \%)$ dan kriteria DMF-T sangat tinggi berjumlah 5 orang $(3,57 \%)$.

Setelah distribusi karies, jumlah dan prosentasenya diketahui, distribusi hasil kuisioner pola menyikat gigi, jumlah dan prosentasenya seperti dapat dilihat pada Tabel 3 .

Dari Tabel 3 terlihat frekuensi orang yang menyikat gigi kurang dari satu kali dalam sehari berjumlah 20 orang (14,29\%), frekuensi menyikat gigi dua kali sehari 52 orang $(37,14 \%)$, dan frekuensi menyikat gigi lebih dari dua kali sehari berjumlah 68 orang $(48,57 \%)$. Mengdistribusi waktu menyikat gigi, waktu menyikat gigi setelah makan dan sebelum tidur berjumlah 20 orang $(14,29 \%)$, waktu menyikat gigi sesudah makan berjumlah 37 orang $(26,43 \%)$, waktu menyikat gigi sebelum tidur berjumlah 23 orang $(16,43 \%)$, waktu menyikat gigi 
saat mandi berjumlah 60 orang $(42,86 \%)$. Distribusi tehnik atau cara menyikat gigi maju mundur sebanyak 46 orang $(32,86 \%)$, cara menyikat gigi atas kebawah sebanyak 29 orang $(20,70 \%)$ dan cara menyikat gigi kombinasi sebanyak 65 orang $(46,43 \%)$. Untuk bahan menyikat gigi dengan pasta gigi sebanyak 140 orang (100\%), bahan menyikat gigi dengan serbuk batu-bata dan lain-lain tidak ditemukan, dilakukan uji Chi-Square $\alpha=0,05$ untuk mengetahui hubungan antara pola menyikat gigi dengan karies gigi (Tabel 4.)

Tabel 2. Distribusi karies, jumlah dan prosentasenya

\begin{tabular}{lcc}
\hline \multicolumn{1}{c}{ Kriteria DMF-T } & Jumlah & Prosentase (\%) \\
\hline Sangat rendah (0,0-1,1) & 0 & 0 \\
Rendah $(1.2-2.6)$ & 13 & 9,28 \\
Sedang & 82 & 58,57 \\
Tinggi & 40 & 28,57 \\
Sangat tinggi & 5 & 3,57 \\
Jumlah & 140 & 100 \\
\hline
\end{tabular}

Tabel 3. Distribusi hasil kuisioner pola menyikat gigi, jumlah dan prosentasenya

\begin{tabular}{|c|c|c|c|}
\hline No & Pola menyikat gigi & Jumlah & $\begin{array}{c}\text { Prosentase } \\
(\%)\end{array}$ \\
\hline 1 & $\begin{array}{l}\text { Frekuensi menyikat gigi } \\
\text { dalam sehari } \\
\text { a. Kurang dari satu kali } \\
\text { b. Dua kali } \\
\text { c. Lebih dari dua kali }\end{array}$ & $\begin{array}{l}20 \\
52 \\
68\end{array}$ & $\begin{array}{l}14,29 \\
37,14 \\
48,57\end{array}$ \\
\hline 2 & $\begin{array}{l}\text { Waktu menyikat gigi } \\
\text { a. Setelah makan dan } \\
\text { sebelum tidur } \\
\text { b. Sesudah makan } \\
\text { c. Sebelum tidur } \\
\text { d. Waktu mandi }\end{array}$ & $\begin{array}{l}20 \\
37 \\
23 \\
60\end{array}$ & $\begin{array}{l}14,29 \\
26,43 \\
16,43 \\
42,86\end{array}$ \\
\hline 3 & $\begin{array}{l}\text { Cara menyikat gigi } \\
\text { a. Maju mundur } \\
\text { b. Atas bawah } \\
\text { c. Kombinasi }\end{array}$ & $\begin{array}{l}46 \\
29 \\
65\end{array}$ & $\begin{array}{l}32,86 \\
20,70 \\
46,43\end{array}$ \\
\hline 4 & $\begin{array}{l}\text { Bahan menyikat gigi } \\
\text { a. pasta gigi } \\
\text { b. serbuk batu bata } \\
\text { c. lain-lain }\end{array}$ & $\begin{array}{c}140 \\
0 \\
0\end{array}$ & $\begin{array}{c}100 \\
0 \\
0\end{array}$ \\
\hline
\end{tabular}

Tabel 4. Uji Chi-Square antara pola menyikat gigi dengan karies gigi Chi-Square Tests

\begin{tabular}{lccc}
\hline & Value & df & $\begin{array}{c}\text { Asymp. Sig. } \\
(2-s i d e d)\end{array}$ \\
\hline Pearson Chi-Square & $37.775^{\mathrm{a}}$ & 8 & .000 \\
Likehood Ratio & 43.407 & 8 & .000 \\
Linear-by-Linear & & & .000 \\
Association & 36.126 & 1 & \\
N of Valid Cases & 140 & & \\
\hline a. 2 cells (25.0\%) have expected count less than 5. The \\
$\quad$ minimum expected count is 2.43
\end{tabular}

Dari hasil analisis data menggunakan uji chisquare dengan $\mathrm{df}=8$, didapatkan nilai $\mathrm{X}^{2}$ hitung $=$ 37,78 , sedangkan nilai $X^{2}$ tabel $=15,51$.

\section{Pembahasan}

Dari Tabel 2, ditemukan kriteria DMF-T tertinggi adalah kriteria sedang yaitu sebanyak 82 orang $(58,57 \%)$, serta tidak ditemukan subyek dengan kriteria DMF-T sangat rendah. Dari tabel 3. didapatkan frekuensi menyikat gigi terbanyak adalah lebih dari dua kali sehari yaitu 68 orang $(48,57 \%)$, waktu menyikat gigi pada saat mandi pagi dan sore yaitu 60 orang $(42,86 \%)$, cara menyikat gigi terbanyak adalah kombinasi maju mundur dan atas bawah sebanyak 65 orang $(46,43 \%)$, serta bahan menyikat gigi dengan pasta gigi (100\%).

Hasil analisis data dengan menggunakan uji chi-square dengan $\mathrm{df}=8$, didapatkan nilai $\mathrm{X} 2$ hitung $=37,67$, sedangkan nilai $\mathrm{X} 2$ tabel $=15,51$, dengan $\mathrm{X}^{2}$ hitung $\geq \mathrm{X}^{2}$ tabel yang menunjukkan bahwa terdapat hubungan antara pola menyikat gigi dengan karies gigi pada masyarakat desa Puger Kulon. Jika pola menyikat gigi benar maka karies gigi rendah, sebaliknya jika pola menyikat gigi salah maka karies gigi tinggi. Diperkirakan hubungan ini disebabkan karna waktu menyikat gigi yang hanya dilakukan pada saat mandi pagi dan pada sore hari, sedangkan menyikat gigi setelah makan dan sebelum tidur malam jarang dilakukan. Houwink (1993), ${ }^{7}$ waktu yang baik untuk menyikat gigi adalah sesudah sarapan pagi dan sebelum tidur malam. 
Symmetric Measures

\begin{tabular}{lcccc} 
& Value & Asymp Std. Error & Approx. $1^{\text {-b }}$ & Approx. Sig. \\
\hline Interval by Interval Pearson's R & -.510 & .05 & -6.961 & $.000^{\mathrm{c}}$ \\
)rdinal by Ordinal Spearman Correlation & -.519 & .060 & -7.133 & $.000^{\mathrm{c}}$ \\
Vof Valid Cases & 140 & & & \\
\hline
\end{tabular}

". Not assuming the null hypothesis.

". Using by asymptotic standard error assuming the null hypothesis.

$\therefore$ Based on normal approximation.

\section{Kesimpulan}

Berdasarkan pembahasan hasil dan analisis data yang telah diuraikan pada bab sebelumnya, maka dapat disimpulkan :

1. Kriteria DMF-T masyarakat desa Puger Kulon adalah sedang $(58,57 \%)$

2. Kecenderungan frekuensi menyikat gigi adalah lebih dua kali dalam sehari $(48,57 \%)$

3. Umumnya cara menyikat gigi adalah kombinasi maju mundur dan atas bawah $(46,43 \%)$

4. Memakai pasta gigi dalam menyikat gigi $(100 \%)$

5. Ada hubungan antara pola menyikat gigi dengan prevalensi karies gigi masyarakat desa Puger Kulon.

\section{Daftar Pustaka}

1. Tarigan R. Kesehatan Gigi dan Mulut. Jakarta : EGC. 1989.

2. Kuntari. Hubungan Antara Kebersihan Gigi Dan Karies Gigi Pada Anak Usia 4-6 Tahun Di Kotamadya Surabaya, Surabaya: MKG FKG Unair Surabaya. 1996; 29 (1).

3. Nunung $R$, Zubaidah $C$. Hubungan Frekuensi Menyikat Gigi Dengan Indeks Gingivitis Pada Ibu Rumah Tangga Di Perkebunan Purbasari Pengalengan Bandung, Jakarta : Majalah Ilmiah Kedokteran Gigi FKG USAKTI. Edisi Khusus Foril IV. 1993

4. Boediharjo. Surabaya: Airlangga University Press. 1989.

5. Suwelo. Karies Gigi Pada Anak dengan Pelbagai Faktor Etiologi. Jakarta : EGC. 1992.

6. Badan Pemberdayaan Masyarakat. Profil Desa Puger Kulon. Jember : Kabupaten Jember. 2003.

7. Houwink, B, et. al. Alih bahasa Sutatmi dan Rafiah Rabyyono. Ilmu Kedokteran Gigi Pencegahan. Yogyakarta : Gajah Mada University Press. 1993. 